\title{
Application of IoT in the Development of Intelligent Education System - A Thematic Literature Review
}

\author{
Vinayachandra ${ }^{1,2} \&$ Krishna Prasad K. ${ }^{3}$ \\ ${ }^{1}$ Research Scholar, College of Computer Science and Information Science, Srinivas University, \\ Mangalore, India \\ ${ }^{2}$ Assistant Professor, Dept of Computer Science, St Philomena College, Puttur, India \\ ${ }^{3}$ College of Computer Science and Information Science, Srinivas University, Mangalore, India \\ E-mail: veeciashu@gmail.com
}

Area/Section: IT Management.

Type of the Paper: Review Paper.

Type of Review: Peer Reviewed as per $|\mathrm{C}| \mathrm{O}|\mathrm{P}| \mathrm{E} \mid$ guidance.

Indexed in: OpenAIRE.

DOI: http://doi.org/10.5281/zenodo.3775850.

Google Scholar Citation: IJMTS.

\section{How to Cite this Paper:}

Vinayachandra, \& Krishna Prasad, K. (2020). Application of IoT in the Development of Intelligent Education System - A Thematic Literature Review. International Journal of Management, Technology, and Social Sciences (IJMTS), 5(1), 124-146. DOI: http://doi.org/10.5281/zenodo.3775850.

International Journal of Management, Technology, and Social Sciences (IJMTS)

A Refereed International Journal of Srinivas University, India.

(C) With Authors.

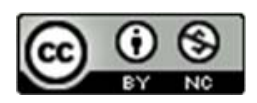

This work is licensed under a Creative Commons Attribution-Non-Commercial 4.0 International License subject to proper citation to the publication source of the work.

Disclaimer: The scholarly papers as reviewed and published by the Srinivas Publications (S.P.), India are the views and opinions of their respective authors and are not the views or opinions of the SP. The SP disclaims of any harm or loss caused due to the published content to any party. 


\title{
Application of IoT in the Development of Intelligent Education System - A Thematic Literature Review
}

\author{
Vinayachandra ${ }^{1,2}$ \& Krishna Prasad K. ${ }^{3}$ \\ ${ }^{1}$ Research Scholar, College of Computer Science and Information Science, Srinivas University, \\ Mangalore, India \\ ${ }^{2}$ Assistant Professor, Dept of Computer Science, St Philomena College, Puttur, India \\ ${ }^{3}$ College of Computer Science and Information Science, Srinivas University, Mangalore, India \\ E-mail: veeciashu@gmail.com
}

\begin{abstract}
Smart Education System makes efficient use of IT technology that takes advantage of IoT and cloud computing technologies to track and act on multiple educational system components. To maximize the battery life of IoT nodes, the systems need to provide access to nodes and gateways by that introduce an architecture that allows not only the latest wireless and wired technologies to provide a fair communication range but also reduced energy usage. Like other sectors integrating intelligent cultures, the education sector is no exception to this. The IoT confirms its important role in the field of Information and Communication Technology and social growth. More devices are linked in education; campus leaders will be able to derive even more value from the continuous stream of data and knowledge, helping them transition from a transactional relationship to an iterative process with students, teachers, administrators, and providers. A small, person-centered environment helps smart campuses to complement and fit with the overall smart environment strategy, allowing educational institutions to achieve full productivity, promote sustainability, and enhance their constituents' everyday conditions. This analysis of the literature is generated using the secondary data obtained by reviewing a good number of papers published in journals and online sources. The study aims to explain IoT's use in the growth of the Smart Education System. The limitation of the study is that it deals only with the subject matter's application components which leave physical components.
\end{abstract}

Keywords: Intelligent Education, IoT, Smart Education, Cloud Computing, Smart Campus, Senor, Actuator, teaching-learning.

\section{INTRODUCTION :}

IoT has the potential to add tremendous value to institutions of higher learning. Educational Institutions have great opportunities to benefit from IoT systems. Students may be given smart cards with IOTs. Students can obtain access to the grounds, laboratories, classrooms, libraries, etc. by using these smart cards. When a student enters the campus, he will receive reminders about the availability of reserved books in the library, his/her daytime schedules, etc. Students can get the custom schedule and venue of his classroom in a choice-based program as soon as he enters the campus (Mrabet\&Moussa2017) [1]. A student can have great freedom to pick up his or her subjects or documents. This could be used by a biometric attendance program to track student attendance. It could later be linked to scholarships, mobile phones for parents, etc. Student wellbeing and hostel inmates may be tracked via the adoption of fitness apps. Automatic monitoring of temperatures may be done in laboratories and laboratory equipment. You could do interactive projectors, touch screens, automatic reading capture (Satu et al. 2019) [2]. You can attach touch boards to the internet, where you can download the stuff you need directly to the board. It allows staff and students to connect themselves with worldwide educational tools resulting in robust \& hybrid learning environments. The database of the 
research submitted by the student could be preserved and evaluated to give students personalized advice (Pervez et al. 2018) [3]. If the conduct of the students after review shows that they are failing academically or socially, custom warnings can be provided so that administrators can respond quickly to fix issues. Profiles of students may be built up throughout their association with campus to assist them with work activities. Smart apps will alert workers and suppliers when to service equipment before it even presents itself with a problem. Smart doors, locks, and cameras can be used in different facilities to track and regulate movement. Customized learning could easily be done at one's speed and intellectual capacity (Mahmood et al. 2019) [4]. Prepaid canteen services may be offered with the help of smart cards. The IoT also lets administrators link all on campus, via a single stable, centralized network anywhere to control campus lighting, parking, and cameras, and provide useful data and analytics for resource optimization (Huda \& Arwa 2018) [5]. The system is not free from challenges. A notable a few are: Big data development may be a bigger threat, because more computers, vehicles, homes, and other objects would be connected to the internet in the future. Many networking standards for both wired and wireless devices have yet to be developed to allow communication between different devices. Information protection and privacy could pose a greater danger because all data is stored in databases and access to sensitive and essential data can be easily accessed. High speed wideband shall be made available everywhere. Energy is also important, as many IoT systems take years to operate (Kavitha \& Lakshmi 2016) [6]. This analysis of the literature is generated using the secondary data obtained by reviewing a good number of papers published in journals and online sources. The paper throws light on (i) IoT based Smart Environment, (ii) IoT Applications in the Education Industry, (iii) IoT in Education, (iv) How education industry is using IoT to its benefit, (v) Advantages of IoT Solutions for the Education Domain, (vi) Support directives for an Intelligent Environment, (vii) Important aspects for effective implementation of IoT in education, (viii) Summary of Literature
Review, (ix) Future of the IoT in Education,(x) Research Gap, (xi) Research Agenda, and (xii) Conclusion.

\section{BACKGROUND AND MOTIVATION :}

Work is essential to the future gain and the effect of the IoT evolution principle is same in both learning environments - physical \&virtual. It is important to examine the use of the IoT in the later and e-learning programs within an intelligent campus. Besides, the usage of the smart city model is evident where improved accessibility and interoperability improves the services offered to residents. Increased connectivity and device smartness will improve the value-added and smartness of the educational system to provide services to the learner. New applications are emerging day after day in the light of recent research in this field. The targeting of users interested in using the technology for education is common to the applications, as these users are by definition digital natives. But it is for educational purposes to explore and build upon the latest paradigm. Regardless of the paradigm's features, the user should be able to access just-intime information on a network of devices capable of holding machine-to-machine (M2M) communications with each other and other consumer devices (such as smartwatch or smartphone). This research tries to discover details of these interactions in scenarios that relate to the smart physical campus. The use of IoT to improve the educational experience for students, faculty members, and other team members provide possible new learning opportunities and scenarios. The limitation of the study is that it deals only with the subject matter's application components which leave physical components (Elsaadany \& Soliman 2017) [7].

\section{RESEARCH AIM AND METHOD :}

This qualitative analysis, based on the business model of education. The main aim of this work is to gain an understanding of the situations that require the introduction of IoT in education, the benefits of this integration, and the difficulties in such an environment. Furthermore, this study is intended to provide a context for promoting new research activities on this subject. To fulfill its aim, this research formulated the following 
questions:

- RQ1: How has IoT Applications influenced Smart and Intelligent Education System development?

- RQ2: What are the technological and architectural criteria for the Smart and Intelligent Education System?

Five sub-research questions arose to encourage the answer to the first question with the limit of scenarios discussed:

- RQ1.1. What level(s) of education is presented?

- RQ1.2. What subject(s) of education is discussed?

- RQ1.3. What perspective(s) was presented, for example, by the teacher, student, and staff?

- RQ1.4. What learning concepts are addressed?

- RQ1.5. What educational environments are dealt with?

The emphasis of this paper is above research questions, and we also pose several research gaps concerns that we address in Section 4.9 based on the discussion.

\section{LITERATURE REVIEW :}

Educational institutions have continually adopted technology as this may be one of the most important factors for improving learning outcomes. More than just hiring a teacher, submitting a library, or studying in the field, IoT has also found that consumers are interested in education, such as flipped classrooms, Virtual Reality and Augmented Reality enabled smart boards or accessing safe learning spaces (Abbasy $\&$ Quesada 2017) [8]. In terms of education, IoT is dignified to play the role of a big game-changer as this technology is now utilized by many educational institutions. Along with that, connected smart devices are used by many institutions for supporting the even now available e-learning and smartboard infrastructure. Some reasons are mentioned below:

- As cloud service is easily available and also affordable, it plays a key role to increase the popularity of IoT-enabled devices.
- Unlimited storage with pay as the user makes it easier or cheaper to store, analyze, and access the data.

- A highly customized application has been created to meet the needs of the educational institution.

- IoT technology has the power of making life easier for each stakeholder, including students, educators, management, and parents (Zhamanov et al. 2018) [9].

Applications of IoT are designed for the almost all facets of the field of the education, such as

- A solution for educators that facilitates stakeholder interaction

- Application management solution for feasibility and cost optimization

- Classroom management solutions for improving education

\subsection{IoT BASED SMART ENVIRONMENT}

Mark Weiser's theory of smart environments tells us that there should be smart tools and smart environments everywhere ready for us to perform daily tasks. Smart environments may include smart houses, smart workplaces, smart classrooms, and other intelligent areas. The primary aim of smart environments based on IoT is to offer ease in the daily routine tasks. Through using sensors, actuators, and smart devices, all this information can only be accessed from one's voice.

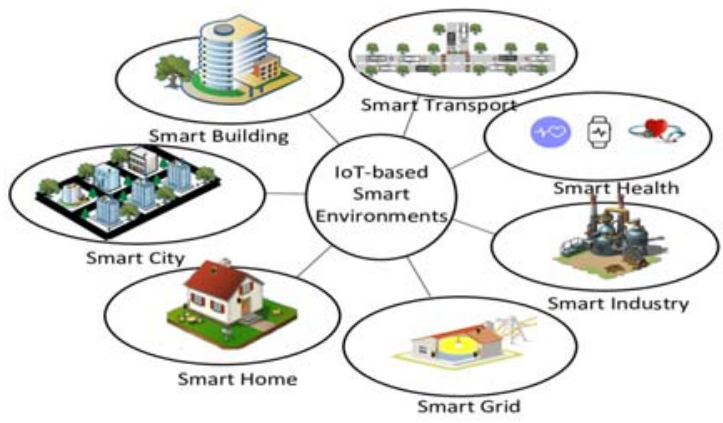

Fig. 1: IoT based smart environment (Ahmed et. al 2016) [10].

In the Smart world, three primary goals are understanding, reasoning, and prediction. In other words, creative environments need to know and appreciate how the world functions and thinks, and they need to be able to respond to the action or circumstance. An intelligent environment can 
be described "as one that can acquire and apply information about the world and its inhabitants to enhance their experience in this area" (Gul et al. 2017) [11].

\subsection{IoT APPLICATIONS IN THE EDUCATION INDUSTRY :}

IoT may help to make education more geographically available, capabilities, and status. The opportunities to integrate IoT-enabled solutions to the school environment are endless. These serve as the strong base on which to make a wide understanding of its the application in education. Further, technology can improve teaching rather than hiring new staff. Some teachers and students need technical support to showcase their teaching talent. IoT Solutions for Education understands this and provides solutions that improve the quality of education worldwide. The opportunities once enjoyed by healthy students were now evenly distributed among students with disabilities. Simplified expressions of complex formulas, ideas, and theories are now a clear possibility (Basset et al. 2019) [12]. Learning in the classroom has become fun, interesting, and interactive. Indeed, IoT devices have been able to balance a significant amount of modern education to fully promote global society. It has never been accessible and interactive in education. IoT in education is essentially the future of scholars. With IoT, instructors have easy access to powerful teaching tools. Teachers can use IoT to provide student-specific one-on-one instruction to each student with a specific educational design. For example, it uses data to determine the most effective supplement for each student and automatically generates content from the student's on-demand lesson content (Xue et al. 2011) [13]. Application of technology in the education spectrum improves the professional development of scholars because they understand that they truly work and learn to create better strategies, as well as repeating old or invalid practices. IoT also enhances the knowledge base used to implement standards and practices in education. Educational research is suffering from accuracy problems and a general lack of data. IoT is a massive, high-quality, real-world dataset focused on teaching design (Zhong et al. 2017) [14]. It is derived from the unique ability of IoT to collect a large amount of strange information everywhere. Also, IoT helps each student learn adaptation by giving them access to their needs. Every student can monitor his or her experience and participate in the design of instructions. Many are done passively. Students simply use the system, and the performance data essentially shapes the design. This offers highly effective education, thus reducing the costs of planning and adapting education (Ahlmeyer \& Chircu 2016) [15].

\section{Smart Classroom}

Classrooms fitted with IoT tools can be used to track and evaluate the students' performance and effectiveness. IoT devices will monitor students' attendance automatically. Teachers and educators are now required to remotely administer tests and assignments. The students' safety can also be monitored using IoT wrist bands. For any potential learning space inside the classroom, ventilation, air quality, temperature, and humidity can also be managed and optimized. This will ensure that the facilities are run smoothly and will encourage a personalized active learning (Bijju et al. 2011) [16].

\section{Smartboards}

Now that time has changed, students enjoy smarter boards than blackboards. A smartboard is an interactive whiteboard that projects an image of the subject. Allow teachers and students to interact with it. Simply enter or rotate in class. At this point, it seems to be more fun and exciting. It is common to consider whether a smartboard can replace a blackboard by any means. The answer is yes. Blackboard and textbook words and images are too short to communicate the concept of the text within minutes. Perception conflicts become commonplace and the classes are pools of confusion. Here, the application of IoT in education has made learning and information exchange easy, interesting, and interactive. With a smartboard, teachers can take a deep breath. Infographics, tutorial videos, and complex formulas can be solved quickly, especially in math (Aldowah et al. 2017) [17].

\section{Attention to Attendance}

The rules are separated by the educational 
institution. Some feel that a certain percentage of students need to take the exam. With IoT, managers can find accurate information about attendance. There is no human error in the data. The hostel's students' real-time location can determine safety and quality of life (Wan \& Zeng 2015) [18]. For management, attendance is frustrating to count. The IoT-based attendance system makes it easy for students to calculate attendance and regularity, punctuality, and personality reports. Time savings can have a big effect on lab employee satisfaction. Also, IoT has identified the need to digitally register attendance to make students more regular in the classroom. If a student goes missing from an educational institution for any reason, a simple electronic message will be sent to the parents. This is a very good measure of security (Ali et al. 2017) [19].

\section{Significant Safety}

Whatever the fun form of security for emergency indicators, audio enhancements, Wi-Fi watches, and deaf notifications, the lab has a short circuit, and the IoT sensor detects it instantly and sends an instant alert to reverse the situation. If someone gets stuck in the elevator, an "auto" realtime alert will also be sent. In our note of serving, the significant impact of globalization can be seen in various forms of the world. The probability of an earthquake is suddenly changing with severe weather and becoming commonplace. This is because schools and other educational institutions invest in IoT sensors and meters when concerns about natural disasters occur (Uskov et al. 2016) [20].

\section{Adjusting Disability}

A few years ago, it was very difficult for children with disabilities to learn and reflect on new things. The modern technical design allows them to learn and perform new things just like any other skilled student. Some segments of the population are challenged with hearing loss. With an integrated glove and tablet system, conversations can be translated into sign language. The incentive to convert words into written words is noteworthy. The world of children with disabilities is bright because IoT devices lead to providing educational support to children with disabilities in a constructive way. It guides their intelligence and passion for trivial success (Alnahdi \& Liu 2017) [21].

\section{Mobile Apps and Tablets}

Millennial students need to restrict the use of gadgets. Unfortunately, however, the lives of these modern students seem to revolve around smartphones, tablets, and other screen-based electronics. IoT specialists have shifted this particular focus to educational themes in gaming and social networking gadgets. It is now easier to engage people around the world with the same goals and interests (Tianbo 2012) [22]. The Internet of Things of Education sensor collects data and automatically suggests academic topics of interest to students sitting on the other side of the screen. The use of smartphones and tablets is helpful for students' grades almost overnight.

\subsection{THE ROLES OF IoT IN EDUCATION :}

A very smart component of today's universities and classrooms is that IoT improves schools and improves fees for physical services and systems. An elusive university has the advantage that it can easily provide a better level of knowledge at the individual level. Smart gadgets are used throughout campus to employ the Wi-Fi community to transmit information and receive orders (Sklavos et al. 2017) [23]. Further, the computational IoT gadgets for facility and learning facilities help to create smarter lesson plans, maintain coordination with key resources, and improve admission records, design secure campuses, and so on. The Internet of Things will integrate into more education systems shortly. Many schools use this to train their students for greater understanding and other schools may use it to save data and save resources and other similar needs (Assante et al. 2018) [24]. IoT needs to change the understanding of education to integrate into education. The educational institutions that make practical and reasonable products the educators, students, and administrators 


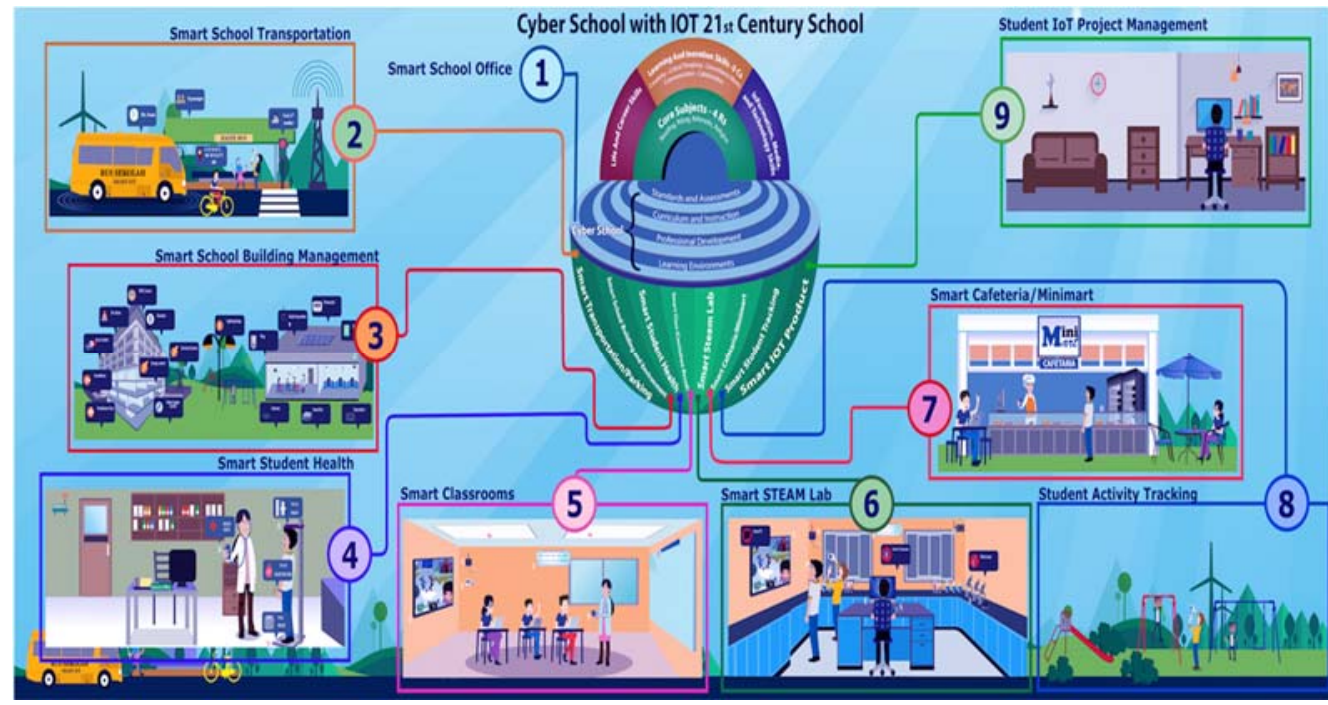

Fig.2: IoT's Application in Education

Source: https://data-flair.training/blogs/iot-in-education/

\section{Interactive Learning}

Today, learning is more than just a combination of images and text. Many textbooks have been added to web-based sites, with additional videos, materials, animations, ratings and other content to assist in the learning process. It provides a broader perspective for students to gain knowledge about new subjects, including better understandings and communication with teachers and friends. The actual professional problems are discussed by the education professionals in the classroom and the students produce answers to these issues (Bagheri \& Movahed 2017) [25].

\section{Security}

It is not an easy task to track each student's location and activities, because many student organizations attend classes. Also, institutional students are at greater risk than other workplace populations and their need for intelligent protection can add a lot of value to the security of IoT schools, universities, and other learning centers. Strategies such as 3D positioning allow students to be tracked 24/7 at any time and report their presence. These technologies can also provide a sad button option for triggering alarms where needed. Recently, significant improvements have been made to computer vision technology, which allows the speed monitoring of signatures. This activity allows you to automatically prevent unexpected events from occurring (Saravanan et al. 2019) [26].

Educational application
The educational applications of the benefits of IoT are seen as a powerful creative tool and teaching and learning methods are changing. Teachers and students can create and take notes in 3D graphic textbooks using video. This app can be considered a game-changer because of the large number of educational games available. These games offer a lot of features that offer interesting teaching and learning possibilities. It has made education more attractive than ever (Banica et al. 2017) [27].

\section{Increase efficiency}

Most schools invest several times on events that do not respect their existence's main purpose. For example, students need to be present several times a day. This information must also be forwarded to the central office aimed at specific purposes. IoT can eliminate this inefficient system. This data so collected sent to a central data server with IoT end devices, which automatically eliminates the need for data interference. This revolutionary change in IoT can reduce the tedious work of teachers and students. Students will focus more on teachinglearning as it the heart of the education system (Roy et al. 2016) [28].

These are some significant territories where the IoT can be applied

\section{A. Poster-boards into IoT-enabled boards}

This is certainly very problematic tolerate the presentation board of older age with the multimedia poster board of these days. Era 
presentation boards with present-day multimedia poster boards. It is to be sure hard to contrast the established time introduction loads up and present-day sight and sound notice load up. Webequipment like Glogster has improved this simplicity and allows the people for creating digital posters without any issue merging with video, photos, text, hyperlinks, and audio. Such interactive boards could then be distributed via email to cohorts and educators (Bhatt \& Bhatt 2017) [29].

\section{B. Interactive gaining of knowledge}

Becoming familiar with the modern era isn't controlled to the blend of pictures and texts yet something more than that. It gives the students a more comprehensive viewpoint to breakdown things with cleariunderstanding and interaction with their educators and their companions. Besides, the instructional experts are bringing genuine world difficulties in the exam room and allow the students to locate their answers (Chatterjee et al. 2018) [30].

\section{Learning at any-time and any-where}

IoT plays a significant role to develop a system using extraordinary web-based frameworks. Cutting edge creativity gives the scholastic the power to demonstrate the researchers' advancement. Edmodo is a tremendous form of verbal communication between teachers and students. Edmodo brings newcomers the potential to benefit data from any area whenever they are. IoT permits students and educators to impart using remarkable strategy, reading messages, and forthcoming occasions simultaneously when away from the study hall or in any event, answering to posts. It likewise permits a client to spare their particular notions and class undertaking without stressing and guarantee them their full privacy (Riggins \& Wamba 2015) [31].

\section{Higher safety features}

This application is critical because it could be useful to incorporate the superior innovation responses inside the school rooms and to prepare territory. This provides crisis markers, sound enhancement, Wi-Fi tickers, and hearing impeded alerts that give a sense of security to researchers and a variety of staff (Xia et al. 2012) [32]. The IoT empowered interchanges framework likewise be used for diverse cases, e.g. exceptional crisis tones, live announcements, and pre-recorded instructional messages to coordinate the gathering of laborers and students at some pointy of crisis (Bogdanovic et al. 2014) [33]. A student GPS tracker is a small tracking device that can be placed in the pocket, knapsack, or coat of the student. A student's location can be identified using satellite dependent positioning. A GPS tracker can also be placed imperceptibly in spots such as a stroller, allowing a student to be tracked via a GPS tracker (Mathew \& Gondkar 2017) [34].

\subsection{HOW EDUCATION INDUSTRY IS} USING IoT TO ITS BENEFIT :

The most critical activity for any developing society is imparting education. So, it becomes obvious to utilize the advanced technology of modern days to make learning more effective, vivid, and fun for the students.

\section{i. Smart automated student tracking}

With the help of the system of smart automated student tracking, it probably won't be vital for the students to be present at a given time in a given place to be marked present. Moreover, students are allowed by it to seek after their benefits as long as they are signed into the system of automating tracking (Plauska \& Damasevi 2014) [35].

\section{ii. Personalized learning}

As all students bare not the same, particular ways to deal with learning can draw out the best of their capacities. The efficiency of education along with the maintenance of data can be increased by personalization and absence of personalization it becomes difficult for some students to draw out the best of their capacities (Bautista et al. 2019) [36]. For instance, students with dyslexia are generally intellectually equivalent or higher than the greater part of their companions, yet typical learning techniques aren't appropriate for them. It cannot be possible to teach them with the help of textbooks. Then again, instruments like speechto-content programming permit them to utilize their voices to finish composed assignments so their outcomes aren't reliant on their capacity to peruse and compose (Chin \& Callaghan 2013) [37].

Gathering information about the performance of 
the students during the test just as lessons empowers the teachers to customize further learning according to their enthusiasm just as their abilities. This turns out to be much progressively urgent for higher investigations where students have better possibilities at finishing their examinations if the way is customized for them. Disinterest and distraction of students can be detected immediately by the connected systems (Zhu et al. 2016) [38].

iii. IoT empowered smart boards and the new generation textbooks

Envisage a circumstance where the history educator can reproduce the battle of Normandy on the smartboard at the time of teaching World War I. Then again, virtual animals can be dissected by the students at the time of studying science. Then again, a live experience of the eruption of a volcano can be experienced by the class, at the time of studying geography (Wang 2010) [39]. The act of learning will become more immersive using the IoT empowered smartboards and students will be motivated by this to take part in learning. Alongside that, physical course books are costly as well as become obsolete in only several years. Learning content gave on IoT gadgets are consistently forward-thinking and can be redone according to the necessity of the students (Comel 2015) [40].

\section{iv. AI-powered research}

Effective specialists have consistently teamed up to accelerate development by learning from one another. ML along with AI can be utilized for connecting databases, analyzing research data as well as gaining insight into those data for future purposes. As the majority of the examination part is taken over by these interconnected frameworks, researchers can concentrate on the exploration part better (Page 2017) [41].

\section{v. Supporting special-need students}

IoT can be a beneficial aspect for those students who need special care. Voice can be converted by a hearing-impaired student to the text, whereas VR headsets can be used by a visually-impaired student for viewing the smartboard. Along with that, the requirement for building the educational facilities and separate curriculum might be diminished by IoT (Dlodlo \& Kalezhi 2015) [42]. vi. Improved security of learning spaces
It is not that only in terms of the core education Internet of things can assist. Likewise, to improve the security of the learning procedure, IoT plays an important role. a secure and safe environment to impart education is also created by IoT. CCTV cameras are utilized for checking school and college spaces and certifying the safety of the students. Immediate action can be taken if there is an emergency, only when all the CCTVs are connected and constant checking is done by the school authority. It has been watched and demonstrated over and over that a safe educational condition improves participation, focus, commitment, and learning in the students (Ning \& Hu 2012) [43].

vii. Smart learning environments

Many digital components are there in terms of Smart learning environments with the help of which more effective, smoother, and better procedures of learning will be created. Preferably, an exact interaction between the digital and physical realities is created by the Smart learning environments, through which students are permitted to retain data from their environment as well as it also makes the prospects for consistent changes among several learning methods: informal and formal setting, group and individual learning, learning through digital or simple formats, etc. Moreover, how much time is needed by the students for completing the assignment can also be reviewed by the IoT devices (Duan et al. 2017) [44]. This approach can be beneficial for the teachers as they come to know whether the method is working properly or not, in which students require extra help to complete their tasks and what kind of tasks are become difficult or the students. 


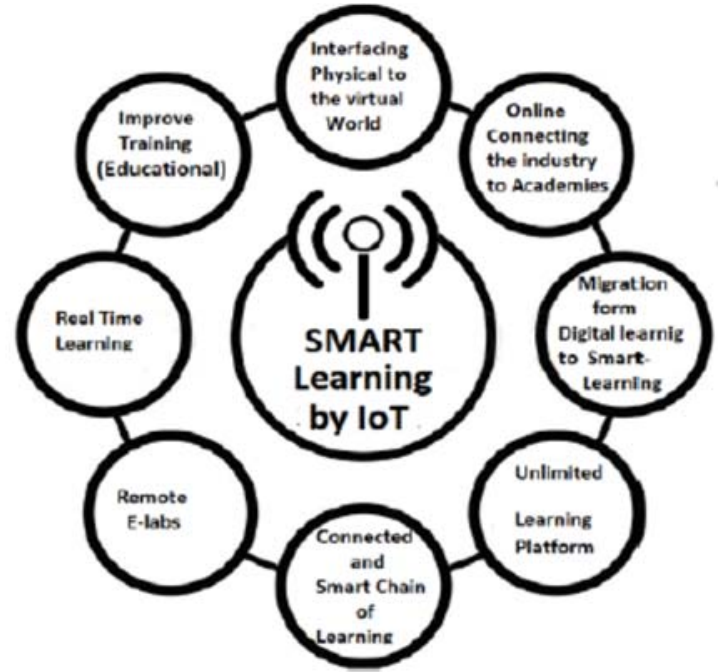

Fig. 3: Smart Learning Dimensions by IoT (Abbasy et al. 2019) [45]

A savvy study hall has AR-empowered smartboards that show advanced and engaging videos on topics being talked about. VR headsets are used by the students to gain immersive knowledge. The instructor can consequently stack assignments and tasks to be done on their devices of the students as the progression of the teaching, now and then just by expressing the project or word assignment, or homework (Moreira et al. 2018) [46].

\section{viii. Task-based learning}

Through the flipped classroom, before coming to the class, students gain the basic knowledge of the topic which will be covered in the class. To certify the full perception of the topic, the acts of learning in the classroom become more taskbased. Those devices which are linked with the IoT network certify that students work together and share their knowledge for completing the assigned task in a better way. As well it ensured by the IoT devices students can be able to take the help of their teachers wherever and whenever needed (Mohapatra et al. 2018) [47].

\section{ix. Augmented and virtual reality}

Even though AR and VR may sound excessively costly for use in the classroom daily, it becomes more affordable and available with the help of products like Google Expeditions. A vast range of virtual possibilities is opened by this tool, such as students can be able to visit many geographical locations that are not possible to reach physically (like Mount Everest), besides, they can be able to be "available" at significant events of history. The act of learning comes to be highly visual and hands-on by the usage of this technology as well as students become more excited and motivated to pursue their study (Elsaadany \& Soliman 2017) [48].

\subsection{ADVANTAGES OF IOT SOLUTIONS} FOR THE EDUCATION DOMAIN :

\section{Enhance Efficiency}

It is important to improve the skills of young people to prepare for the upcoming periods. Capacities like proficiency of learning, selfdirection along basic reasoning can be improved enormously utilizing the IoT. The investigation of Houghton Mifflin Harcourt Team uncovered that those students who use tablets to learn Math can enhance their score by $20 \%$. Through giving interactive experiments at the individual level, the modified IoT application can significantly upgrade the efficiency of the students. The IoT innovation additionally infiltrates alongside wearables in the. Even, by using IoT in the smart classroom, the process of learning can become more interesting. The productivity of the students and the teachers can be increased by IoT technology (Mehmood et al. 2017) [49].

\section{Student-Focused Approach}

The act of education requires the interest of the student and also their attention. Education organization is enabled by the IoT innovation to receive the student-centered approach. It is conceivable to get data about the diverted contemplations of students on account of wearables and IoT blend. Teachers are assisted by this to keep up students' core interests. Vital parameters of the students are measured by all the sensor-empowered gadgets, and on that premise, day schools can structure and improve their sustenance programs (Gao \& Bai 2014) [50].

As well the institution can work to reduce the stress as well as to build a student-oriented approach that can devote to their all-round improvement.

\section{Improved Security}

Nowadays, many institutions have remained worried about their security issue. Just employing a security watch isn't sufficient. A critical role is played by the visitor management to ensure the security of the school as well as the security of 
educational institutes. Advancement of the technology can be promptly incorporated into the linked gadgets to improve visitor management. Visitor management will enhance students' protection by implementing a biometric system; identification software along with other redid IoT-based applications (Mavroudi et al. 2018) [51].

\section{Strong Networking}

Global networking is facilitated by IoT among the mentors, students, teachers, and guardians through linked devices. As blurb sheets convert into 'canny' IoT-empowered sheets, and advanced highlighters have emerged, students can be able to interact with their tutors and peers easily, while sitting in the solace of their home or study hall. It is additionally conceivable to improve the learning procedure utilizing the virtual posters as well as the interactive boards by which users will be enabled to share, receive, and recognize the data easily. Another advantage of IoT innovation is that it can give a more extensive standpoint to any idea while encouraging students to dissect and think of their inventive arrangements (Gomez

\subsection{SUPPORT DIRECTIONS FOR AN INTELLIGENT EDUCATIONAL ENVIRONMENT :}

Table-1: Supporting strategies for a smart learning environment (Stoica et al. 2018) [54]

\begin{tabular}{|c|l|l|}
\hline No. & \multicolumn{1}{|c|}{ Support direction } & \multicolumn{1}{c|}{ Meaning } \\
\hline 1 & Conversation, dialog & $\begin{array}{l}\text { The educational atmosphere needs to allow the student to engage in } \\
\text { group discussions on specific topics. }\end{array}$ \\
\hline 2 & Reflection thought & $\begin{array}{l}\text { The educational environment must have student self-assessment } \\
\text { instruments based on success and results, identifying practices and } \\
\text { skills that can be improved for better educational performance. }\end{array}$ \\
\hline 3 & $\begin{array}{l}\text { Innovation, originality, } \\
\text { creativity }\end{array}$ & $\begin{array}{l}\text { To help instruction the educational environment has to rely on new } \\
\text { and emerging technologies. }\end{array}$ \\
\hline 4 & $\begin{array}{l}\text { Self-organization, } \\
\text { self-control }\end{array}$ & $\begin{array}{l}\text { The educational system needs to include the ability to rearrange } \\
\text { resources. I also comprise control mechanisms to enhance its } \\
\text { efficiency over time, refine how it communicates with participants } \\
\text { under different conditions }\end{array}$ \\
\hline
\end{tabular}

Given the functional elements, designing and implementing an intelligent educational system needs to understand the four directions. At first glance, the technical perspective seems accessible: rapid growth in recent years, materialized in multiple "technological revolutions" is an admissible assumption for the concept of adequate infrastructures. Such

\section{et al. 2013) [52]. \\ 5.Efficient Management}

It is a monotonous task to manage the day to day work at colleges and schools. The Internet of Things arrangements can streamline everyday activities and mechanize assignments. Along with that, not only a lot of time is saved by this but also the efforts of the teachers and the management will be saved by it (Marquez et al. 2016) [53]. Subsequently, instructors can concentrate more on educating, and the supervisory crew can focus on other beneficial errands. For instance, RFID innovation is utilized to follow assets like equipment of lab, projectors, and so on. It spares time and empowers the administration to dispose of recruiting individuals to deal with assets. Likewise, the educational institution can get help from an IoT application advancement organization to diminish vitality costs. technological innovations (mobile communications, smart devices, environmental intelligence, cloud computing, fog computing, etc.) along with the rapid digitization of individual everyday activities position him in an original world, commonly called the Internet of Things (IoT). Of course, we must find cloud computing and fog computing among the 
emerging technologies that can be invoked to create an intelligent learning system in the sense of IoT. In this sense, in the ecosystem identified by IoT, we must see the intelligent educational environment as a superior type of manifestation of the knowledge society. The intelligent world thus surpasses the open environment that in turn leads to a virtual educational environment (Stoica et al. 2018) [54].

\subsection{IMPORTANT ASPECTS FOR} EFFECTIVE IMPLEMENTATION OF IOT IN EDUCATION :

As talked about, IoT can affect the act of learning in a basic manner. The fruitful usage of IoT will rely on these six basic components.

\section{Storage}

The hybrid cloud is used by many organizations as their operating infrastructure for hosting IoT applications. The combination institutions' techsavvy students and the proliferation of tablets and mobile devices have opened up new avenues of enhancing the efficacy of business infrastructure, digital technology, research, and learning ecosystem. In ubiquitous computing where the cloud offers seamless access and services to the information infrastructure providers. Educational organizations are increasingly dependent on cloud infrastructures with private cloud computing services, while instructional applications are gradually migrating to public clouds. Enterprise infrastructure in these organizations needs to reduce latency due to the demand for data and material in instructional technology, the enormous increase in audio and video instruction, and the need for networks (Aldowah et al. 2017) [55].

\section{Instructional Technologies}

Learning Management Systems (LMS)such as Moodle and Blackboard are increasingly being used to produce structured/unstructured data in large volumes, such as audio/video content. There is, therefore, a growing need for school rooms equipped with advanced electronic tools such as lecture recording systems and video sharing enables students to access instructional material on demand at all times (Aldowah et al.

\section{7) [55].}

\section{Quality and Ethics}

The standard of online and on-campus education and the increasing educational costs have been intensively discussed in recent years. IoT offers unique opportunities to deliver digital training courses. However, this often creates difficulties in maintaining the quality of teaching and evaluation of students' work. To improve academic quality and address ethical issues within the education system, IoT educational applications allow students, professors, and the researchers to have resources and technology (Aldowah et al. 2017) [55].

\section{Security}

With youngsters being included, protection of the partners and security of information gathered is critical. Educational institution and Guardians require not only to guarantee from the service provider but also successful execution of protection and safety efforts. Likewise, questions like responsibility for personal and collective information should be tended to before IoT can be actualized immensely in the instruction area (Gubbi et al. 2013) [56].

\section{Integrity}

It is likewise imperative to guarantee the respectability of the information being gathered. Right technologies should be used for this. A significant phase in this direction will be the usage of a public platform that can be utilized by all the parties engaged without making additional ventures (Maksimovic 2017) [57].

\section{Education policies}

IoT in training is a basic change in the manner in terms of which instruction is imparted and learning occurs. To any transformational change to be successful, strategy choices need to be taken and actualized by the skilled specialists. On account of actualizing IoT in educational institutions, training arrangements must support the utilization of innovation in study halls and other instructive environments.

\subsection{SUMMARYOF LITERATURE REVIEW:}

Table2: Summary of findings proposed by different authors between 2010 and 2020 . 


\begin{tabular}{|c|c|c|c|}
\hline SN & Author(s) & Year & Inventions/Findings/Results \\
\hline 1 & Wang & 2010 & Developed IoT-based Interactive English Teaching Model. \\
\hline 2 & Xue et al. & 2011 & $\begin{array}{l}\text { The detailed technical architecture of the ubiquitous learning } \\
\text { environment powered by IoT outlined across three main layers: } \\
\text { a layer of perception, a layer of the network, a layer of an } \\
\text { application. }\end{array}$ \\
\hline 3 & Biju et al. & 2011 & $\begin{array}{l}\text { Introduced IoT technology, its future use in the education } \\
\text { sector, and addresses the advantages and challenges of IoT. It } \\
\text { also addressed how IoT technology can encourage a smart } \\
\text { education system or a smart learning environment. }\end{array}$ \\
\hline 4 & Tianbo & 2012 & $\begin{array}{l}\text { Carried out a study of the relationship between IoT and higher } \\
\text { education. }\end{array}$ \\
\hline 5 & Ning \& Hu & 2012 & Presented reorganized U2IoT architecture for future IoT \\
\hline 6 & Chin \& Callaghan & 2013 & $\begin{array}{l}\text { Proposed Educational Living Labs with emphasis on to use of } \\
\text { Pervasive-interactive-Programming, along with the IoT, to } \\
\text { teach programming. }\end{array}$ \\
\hline 7 & Gomez et al. & 2013 & $\begin{array}{l}\text { Proposed a system forcing students to communicate with } \\
\text { physical objects around them that are digitally connected with } \\
\text { a learning subject. }\end{array}$ \\
\hline 8 & Gubbi et al. & 2013 & $\begin{array}{l}\text { Presented the latest trends in applications-driven IoT research } \\
\text { and the need for convergence across many interdisciplinary } \\
\text { technologies. }\end{array}$ \\
\hline 9 & Kortuem et al. & 2013 & $\begin{array}{l}\text { Discussed the possibilities of integrating collaborative learning } \\
\text { into university education on a wide scale. }\end{array}$ \\
\hline 10 & Bogdanovic et al. & 2014 & $\begin{array}{l}\text { Presented a web-service oriented cloud platform for conducting } \\
\text { IoT classes. }\end{array}$ \\
\hline 11 & Plauska \& Damasevi & 2014 & $\begin{array}{l}\text { Presented a principle of collective learning using educational } \\
\text { robots (smart mobile components of IoT). }\end{array}$ \\
\hline 12 & Gao \& Bai & 2014 & Proposed an IoT Acceptance Model. \\
\hline 13 & Wan \& Zeng & 2015 & $\begin{array}{l}\text { Identified key success factors with a grounded theory for } \\
\text { innovation implementation of IoT }\end{array}$ \\
\hline 14 & Cornel & 2015 & $\begin{array}{l}\text { Demonstrated use of IoT by connecting the Arduino platform } \\
\text { to the Xively web service for reading and displaying data from } \\
\text { sensors. }\end{array}$ \\
\hline 15 & Ahlmeyer \& Chircu & 2016 & $\begin{array}{l}\text { Proposed IoT security framework outlining key security criteria } \\
\text { in five areas: "IoT security levels, IoT security activities, IoT } \\
\text { security value chain, IoT security standards, and IoT security } \\
\text { education". }\end{array}$ \\
\hline 16 & Uskov et al. & 2016 & $\begin{array}{l}\text { Described the ontology of IoT applications with special } \\
\text { references to smartness levels, components, features, and } \\
\text { functions in smart engineering education. }\end{array}$ \\
\hline 17 & Zhu et al. & 2016 & $\begin{array}{l}\text { Proposed a research framework on Smart Education with three } \\
\text { essential elements: smart environments, } \\
\text { smart pedagogy, and smart learner. }\end{array}$ \\
\hline 18 & Marquez et al. & 2016 & $\begin{array}{l}\text { Presented a model for incorporating objects accessible with the } \\
\text { Virtual Academic Communities (VAC) in educational } \\
\text { environments. }\end{array}$ \\
\hline 19 & Haroon et al. & 2016 & Reviewed literature research relating to IoT-based Student \\
\hline
\end{tabular}




\begin{tabular}{|c|c|c|c|}
\hline & & & ms. \\
\hline 20 & Abbasy \& Quesada & 2017 & $\begin{array}{l}\text { Theoretically studied, along with statistical analysis, the } \\
\text { predictable effect of IoT in higher education. Presented } \\
\text { "Internet of education things model" and its components are } \\
\text { outlined. }\end{array}$ \\
\hline 21 & Zhong et al. & 2017 & $\begin{array}{l}\text { Reviewed key technologies that encourage intelligent } \\
\text { education. }\end{array}$ \\
\hline 22 & Ali et al. & 2017 & Proposed "IoTFLiP- IoT-based Flipped Learning Platform" \\
\hline 23 & Alnahdi \& Liu & 2017 & $\begin{array}{l}\text { Proposed a new IoT platform providing versatility concerning } \\
\text { location changes. }\end{array}$ \\
\hline 24 & Sklavos et al. & 2017 & $\begin{array}{l}\text { Discussed IoT technologies regarding the security of trusted } \\
\text { devices. Provided Trust Management infrastructure with a } \\
\text { model for hardware system integration. }\end{array}$ \\
\hline 25 & Bagheri \& Movahed & 2017 & $\begin{array}{l}\text { Categorized the implementation of IoT in education as } \\
\text { i) energy management and real-time environment monitoring, } \\
\text { ii) health care monitoring for students, iii) access control for } \\
\text { classrooms, and iv) enhanced teaching and learning. IoT- } \\
\text { impacted places in the business model of education. }\end{array}$ \\
\hline 26 & Banica et al. & 2017 & $\begin{array}{l}\text { Presented a new concept in IT\&C, namely IoT. Also produced } \\
\text { a model of IoT for Academia. }\end{array}$ \\
\hline 27 & Bhatt \& Bhatt & 2017 & $\begin{array}{l}\text { Surveyed the different techniques used as part of the IoT- } \\
\text { enabled e-learning program to provide better knowledge and } \\
\text { immersive learning skills. }\end{array}$ \\
\hline 28 & Mathew \& Gondkar & 2017 & $\begin{array}{l}\text { Worked out the various tools that can be used to capture data, } \\
\text { track it on the cloud, and use analytics to improve the overall } \\
\text { campus infrastructure. It also proposes an architecture to link } \\
\text { these different technologies to the cloud. }\end{array}$ \\
\hline 29 & Page & 2017 & $\begin{array}{l}\text { The necessity to include the IoT hooked on the Industrial } \\
\text { Design Curriculum was investigated. }\end{array}$ \\
\hline 30 & Elsaadany \& Soliman & 2017 & $\begin{array}{l}\text { Experimental evaluation of aspects of the application of IoT in } \\
\text { education is presented and explored with a view to testing } \\
\text { hypothesis collection. }\end{array}$ \\
\hline 31 & Mehmood et al. & 2017 & $\begin{array}{l}\text { Proposed a customized Ubiquitous e-Teaching \& E-Learning } \\
\text { (UTiLearn) platform that leverages IoT, big data, deep learning, } \\
\text { and supercomputing to facilitate intelligent learning in smart } \\
\text { societies. }\end{array}$ \\
\hline 32 & Aldowah et al. & 2017 & $\begin{array}{l}\text { IoT's effect on higher education examined. An overview of } \\
\text { Future IoT-based higher education has also been given. }\end{array}$ \\
\hline 33 & Maksimovic & 2017 & $\begin{array}{l}\text { Analyzes the possibility of Green initiatives being integrated } \\
\text { into IoT and creating G-IoT with innovations such as green } \\
\text { computing, green networking, and smart grid applications. }\end{array}$ \\
\hline 34 & Gul et al. & 2017 & $\begin{array}{l}\text { Presented Smart Campus ecosystem with smart elements such } \\
\text { as smart e-learning, smart classroom, smart lab, smart notes, } \\
\text { etc. }\end{array}$ \\
\hline 35 & Kiryakova et al. & 2017 & $\begin{array}{l}\text { Analyzed how the IoT could change educational practices and } \\
\text { processes. }\end{array}$ \\
\hline 35 & Leiton \& Loaiza & 2017 & $\begin{array}{l}\text { Based on work related to the e-learning opportunities of smart } \\
\text { cities. The work presented a theoretical review. }\end{array}$ \\
\hline
\end{tabular}




\begin{tabular}{|c|c|c|c|}
\hline 37 & Zhamanov et al. & 2018 & $\begin{array}{l}\text { Discussed IoT technology implementation with the flipped } \\
\text { classroom as a component of IoT education. A comparative } \\
\text { study of the data is made between a flipped classroom and } \\
\text { traditional classroom. }\end{array}$ \\
\hline 38 & Assante et al. & 2018 & $\begin{array}{l}\text { Described the European project IoT4SME's early operation, } \\
\text { focused on evaluating the labor market training needs related to } \\
\text { IoT technologies. }\end{array}$ \\
\hline 38 & Chatterjee et al. & 2018 & $\begin{array}{l}\text { Empirical research aimed to recognize certain factors that } \\
\text { influence the successful implementation of the IoT framework } \\
\text { in conjunction with Artificial Intelligence in the education } \\
\text { sector. }\end{array}$ \\
\hline 40 & Moreira et al. & 2018 & $\begin{array}{l}\text { Discussed the potential and evaluated key issues related to the } \\
\text { use of IoT in education. Reviewed and identified applicable } \\
\text { technologies and projects. It also discusses the incorporation of } \\
\text { IoT technology in schoolbooks, including open data. }\end{array}$ \\
\hline 41 & Mavroudi et al. & 2018 & $\begin{array}{l}\text { Analyzed the design of IoT applications in lower secondary } \\
\text { schools, using case studies in which students gathered in a } \\
\text { laboratory and took on the challenging role of Internet of } \\
\text { Things applications designers. }\end{array}$ \\
\hline 42 & Stoica et al. & 2018 & $\begin{array}{l}\text { Analyzed the field of education as an intelligent learning system } \\
\text { in the context of fog and cloud computing. }\end{array}$ \\
\hline 43 & Caviglione \& Coccoli & 2018 & $\begin{array}{l}\text { Proposed a reference architecture for future and big data- } \\
\text { capable e-learning platforms to be built. }\end{array}$ \\
\hline 44 & Van et al. & 2018 & $\begin{array}{l}\text { Described the effect of IoT on higher education where new } \\
\text { technology, smart devices, and technical advances are } \\
\text { progressing every day. It also included a study of conventional } \\
\text { education and online education. }\end{array}$ \\
\hline 45 & Basset et al. & 2019 & $\begin{array}{l}\text { Illustrated the role of the IoT in creating a smart educational } \\
\text { process. }\end{array}$ \\
\hline 46 & Bautista et al. & 2019 & $\begin{array}{l}\text { Presented a conceptual framework for Smart University based } \\
\text { on IoT infrastructure. }\end{array}$ \\
\hline 47 & Abbasy et al. & 2019 & $\begin{array}{l}\text { The work centered on the different benefits of smart e-learning } \\
\text { within the Educational Learning System. In this review, a } \\
\text { theoretical analysis is illustrated. }\end{array}$ \\
\hline 48 & Kassab et al. & 2019 & $\begin{array}{l}\text { Reviewed "Smart Learning" implementation along with } \\
\text { principles that underpin successful learning. }\end{array}$ \\
\hline 49 & Shaikh et al. & 2019 & $\begin{array}{l}\text { Identified conceptual framework for the "Educational Things" } \\
\text { (IoET) environment on the Internet to promote critical thinking } \\
\text { between students. The paradigm uses the theoretical model of } \\
\text { the Jigsaw Cooperative Learning Model and Interaction } \\
\text { Theory, critical thought model of Mezirov, model of ADDIE } \\
\text { and usability model. }\end{array}$ \\
\hline 50 & Songsom et al. & 2019 & $\begin{array}{l}\text { Presented a "Student Interaction Management System } \\
\text { Architecture" using the IoT to capture the Digital Footprint of } \\
\text { HEs. }\end{array}$ \\
\hline
\end{tabular}


encouraging due to the huge potential it has. In any case, making IoT a piece of standard education will require some time. The most essential factor, in this case, is developing the fundamental technologies both open and simple to utilize. There should be an adjustment in the outlook of the instructors, guardians, and students, upheld by the change in the policies related to education.

IoT technology removes the constraint of physical presence and extends access to the redress of any education such as instructors, software, and wherever E-learning is effectively facilitated. IoT aims to have a huge effect on the higher education learning process by giving students and teachers access to international tools and opportunities. Hence one of the main impacts of the IoT-based learning environments is that the roles of traditional students and teachers can be dramatically modified. Students and teachers can practically maintain teaching material and/or laboratory at any time, from wherever they can interact. It is expected that the Internet of Things will facilitate the vast number of research opportunities for educators, students, and researchers around the world. Although it cannot contribute to the success of the great teacher \& students, it can be encouraged by the student judge to include them in the learning process by connecting the real objects in their assignments, homework, and scientific study (Abbasy \& Qusada 2017) [58].

IoT is upsetting numerous territories of our day to day lives. From transportation to the management of the business, IoT's applications are gradually coming to be very common and important to keep up the first ace world of these days. Even though it might not appear to be an undeniable application, the education field has a lot to pick up from the IoT (Kortuem et al. 2013) [59].

IoT is an undeniably significant part of life, around the work environment, and analytics will just normally create and develop to deal with the huge amounts of information produced by the development of the IoT. For the individuals who don't know, the IoT is the idea of essentially associating any gadget by an on/off button to the Internet (as well as to one another). The advanced disruption has just brought about the usage of the web inside the American educational system, along with the procedure of e-learning coming to be very common (Gul et al. 2017) [60]. Another dimension is added by the IoT to this phenomenon, permitting for a more productive and vivid educational experience.

The IoT can be successfully used in secondary school and college settings, where students are as of now moving ceaselessly from paper course books to digital books on PCs and tablets. By utilizing cloud linked gadgets, teachers can track the progress of the students as well as they can monitor the students who require special attention. This flow in connected technology implies that the resource and time of the teacher can be utilized by the teacher on more initiated guidance, as the IoT would robotize forms that were recently directed manually (Kiryakova et al. 2017) [61].

For instance, the presence of the student within the classroom can be detected by sensors refuting the need to take the attendance manually, in this way saving the valuable time. Along with those benefits of IoT technology, it also helps those students who need special attention. They as well become benefitted by this technology. Such as students with impeded vision can be given exceptional cards that are identified naturally and connected devices will be informed to display the text at the larger font than usual. Through these progressions, the IoT can encourage equivalent access to education (Erasmus et al. 2019) [62].

As stated by Hariharasudan and Kot (2018) [63], "Technology allows teachers to design their lesson plans in a way that combines more than one teaching method. Incorporating a variety of technological enhancements enables a teacher to program each and then put learning into the hands of the students". This implies that every student can learn in their specific manner thinking about their own exceptional needs, boosting certainty, and making an elevating procedure of learning. Moreover, adapting the advance technology of IoT at the bigger scope inside the setting of higher education denotes that the possibility to associate with pioneers and experts, elevating an interdisciplinary way to deal with training which is becoming more applicable in these days' world. 
IoT technology has applications not only inside the classroom but also outside the classroom. Such as it helps to track equipment and resources for quick access to schedules, teachers and students can be able to save their precious time and money. Concerning this approach, IoT can be best used to expand vitality effectiveness and decrease working expenses. Another application is inside transport plans; students can be able to track the route of the bus so that they do not need to wait in an unsafe zone (Kelly et al. 2013) [64]. In any case, there are a few concerns with regards to the utilization of IoT. Invariantly, IoT will compel undesirable change upon a previously working educational system at a huge cost. Notwithstanding, Kassab et al. (2018) [65]points out that a large portion of students needs to utilize their cell phones more often within their classroom, along with that greater part of those students desire to use the technology for automating the tasks that are already done by them, like checking the schedule, conducting any research or taking the class note (Riju 2018) [66].

\section{RESEARCH GAP :}

There is a very insignificant amount of study on the application of IoT in the instruction industry. The focus has been given to knowledge management perspectives or initiatives broadly but knowledge sharing has received small attention. However, studies are focusing upon the education industry and they have been undertaken only the technological factors into consideration. This study is tried to fill the gap. Along with that, this research study is exclusive because, in a single study, the complete collection of the organizational variables, demographic variables, the opinion of teachers and students, the comparison of their descriptions and perceptions of the key factors of IoT in education has been taken into consideration.

This literature review revealed major work gaps concerning IoT education and its branches, such as physical systems (Kassab et al. 2019) [67]. These gaps are caused by a large number of everevolving technologies, highly diverse technology domains, various relevant standards, of IoT education's cross-disciplinary nature. Some of the research gap issues we found are:
Research Gap 1: Best tools for IoT pedagogy and the communication components.

Though IoT technology just emerging and is in its infant stage, a wide range of supporting devices such as sensors, actuators, processing elements, and storage based components are made available to the users and it would be difficult to represent specific components sets for any classroom or laboratory requirements. In this regard, there is a huge scope for research to understand and find out an effective and reliable subset of technologies contributing to the development of individual and autonomous components of the intelligent education system.

Research Gap 2: Teachers, staff, and students link and use IoT networks to teach and learn.

The primary prerequisite for an IoT focused education is the use of apt connecting technology. Stakeholders will have access to these developments inside and outside the campus. Which presents a range of financial, security, and privacy concerns? There is also a problem with low power consumption for IoT nodes backed by batteries, high-power requirements for physical devices, and, most notably, bandwidth utilization. Therefore, in resolving these issues there is research potential and seeking a solution for a secure and effective IoT infrastructure as regards its application to the education industry.

Research Gap 3: Education establishments mitigate software, hardware, communication, and storage complexities.

Resources required for the IoT solutions may its hardware, software, communication or storage are highly assorted and complex. There are several application standards for the use of IoT Systems and its resources. Therefore, there is a scope for IoT based Intelligent and Smart Education System must identify acceptable requirements, reconcile variations, and combine requirements.

\section{RESEARCH AGENDA :}

1] What conceptual model will make an educational institution smart and intelligent for the smart \& intelligent teaching-learning process using adaptive IoT infrastructure?

2] What new technology platform can be proposed with the best use of IoT pedagogy 
and communication elements to incorporate an intelligent education delivery system?

3] What IoT Technology can be proposed for educational institutions that reduce the complexities of software, hardware, and connectivity and storage?

4] What IoT framework can be proposed to connect the key stakeholders in the education system under one smart campus solution?

5] What teaching-learning approaches have evolved concerning the IoT framework in educational institutions and will continue to improve?

6] What integrated IoT system can be proposed to incorporate the Smart Higher Education Program

\section{CONCLUSION :}

IoT has immense importance in the education field, as it makes the learning process smart and easier for the students. In addition, it can reshuffle a person's geographical position, as it provides further change in the field of education. In this way the learning experience will be improved by correctly applying the IoT technology and it will also have a healthy learning environment. The goal is to assess the potential benefits of IoT in education and how it leverages the industry while overcoming its challenges and reducing the associated risks. Our future work should concentrate on the implementation of IoT in Higher Education.

\section{REFERENCES :}

[1] EL Mrabet, H., \& Ait Moussa, A. (2017). Smart Classroom Environment Via IoT in Basic and Secondary Education. Transactions on Machine Learning and Artificial Intelligence, 5(4).

DOI :

https://doi.org/10.14738/tmlai.54.3191.

[2] Satu, M. S., Roy, S., Akhter, F., \& Whaiduzzaman, M. (2019). IoLT: An IoT based Collaborative Blended Learning Platform in Higher Education. 2018 International Conference on Innovation in Engineering and Technology, ICIET 2018, 1-6. DOI: https://doi.org/10.1109/CIET.2018.8660931.
[3] Pervez, S., Rehman, S., \& Alandjani, G. (2018). Role of Internet of Things (IoT) in Higher Education. Proceedings of ADVED 2018- 4th International Conference on Advances in Education and Social Sciences, October, 792800.

[4] Mahmood, S., Palaniappan, S., Hasan, R., Sarker, K. U., Abass, A., \& Rajegowda, P. M. (2019). Raspberry PI and role of IoT in Education. 2019 4th MEC International Conference on Big Data and Smart City, ICBDSC 2019, 1-6. DOI : https://doi.org/10.1109/ICBDSC.2019.8645598.

[5] Huda A 1-Qozani1 \& Arwa Aleryani (2018). The Impact of IoT on the Higher Education. Saba Journal of Information Technology and Networking. 6(2). 38-48.

[6] Kavitha, A. V, \& Lakshmi, K. B. (2016). Waves of IoT in Higher Education. International Journal of Innovative Research in Advanced Engineering (IJIRAE), 3(12), 59-61.

[7] Elsaadany, A., \& Soliman, M. (2017). Experimental Evaluation of Internet of Things in the Educational Environment. International Journal of Engineering Pedagogy (IJEP), 7(3), 50. DOI : https://doi.org/10.3991/ijep.v7i3.7187.

[8] Abbasy, M. B., \& Quesada, E. V. (2017). Predictable Influence of IoT (Internet of Things) in the Higher Education. International Journal of Information and Education Technology, 7(12), 914-920. DOI https://doi.org/10.18178/ijiet.2017.7.12.995.

[9] Zhamanov, A., Sakhiyeva, Z., Suliyev, R., \& Kaldykulova, Z. (2018). IoT smart campus review and implementation of IoT applications into education process of university. 2017 13th International Conference on Electronics, Computer and Computation, ICECCO 2017, 2018-Janua, 1-4. DOI : https://doi.org/10.1109/ICECCO.2017.8333334.

[10] Ahmed, Ejaz \& Yaqoob, Ibrar \& Gani, Abdullah \& Imran, Muhammad \& Guizani, Mohsen. (2016). Internet of Things based Smart Environments: State-of-the-art, Taxonomy, and Open Research Challenges. IEEE Wireless 
Communications. DOI: https://doi.org/10.1109/ MWC.2016.7721736.

[11] Gul, S., Asif, M., Ahmad, S., Yasir, M., Majid, M., \& Malik, M. S. A. (2017). A Survey on role of Internet of Things in education. IJCSNS International Journal of Computer Science and Network Security, 17(5), 159-165.

[12] Abdel-Basset, M., Manogaran, G., Mohamed, M., \& Rushdy, E. (2019). Internet of things in smart education environment: Supportive framework in the decision-making process. Concurrency Computation, 31(10), 112. DOI : https://doi.org/10.1002/cpe.4515.

[13] Xue, R., Wang, L., \& Chen, J. (2011). Using the IOT to construct ubiquitous learning environment. 2011 2nd International Conference on Mechanic Automation and Control Engineering, MACE 2011 - Proceedings, 78787880. Ahlmeyer, M., \& Chircu, A. M. (2016). Securing the Internet of Things : a Review. Issues in Information Systems, IEEE INTERNET OF THINGS JOURNAL, 17(4), 21-28. DOI : https://doi.org/10.1109/MACE.2011.5988881.

[14] Zhong, R. Y., Xu, X., Klotz, E., \& Newman, S. T. (2017). Intelligent Manufacturing in the Context of Industry 4.0: A Review. Engineering, 3(5), 616-630. DOI: https://doi.org/10.1016/ J.ENG.2017.05.015.

[15] Ahlmeyer, M., \& Chircu, A. M. (2016). Securing the Internet of Things : a Review. Issues in Information Systems, IEEE INTERNET OF THINGS JOURNAL, 17(4), 21-28. http://www.iacis.org/iis/2016/4 iis_2016 2128.pdf.

[16] Biju Bajracharya, Cody Blackford \& Jeyaprakash Chelladurai Everage, A., (2011). Prospects of Internet of Things in Education System. The CTE Journal. 2(1), 2-18.

[17] Aldowah, H., U1 Rehman, S., Ghazal, S., \& Naufal Umar, I. (2017). Internet of Things in Higher Education: A Study on Future Learning. Journal of Physics: Conference Series, 892(1). DOI : $\quad$ https://doi.org/10.1088/17426596/892/1/012017.

[18] Wan, J., \& Zeng, M. (2015). Research on Key Success Factors Model for Innovation
Application of Internet of Things with Grounded Theory. WHICEB 2015 Proceedings, 647-654.

[19] Ali, M., Bilal, H. S. M., Razzaq, M. A., Khan, J., Lee, S., Idris, M., Aazam, M., Choi, T., Han, S. C., \& Kang, B. H. (2017). IoTFLiP: IoTbased flipped learning platform for medical education. Digital Communications and Networks, 3(3), 188-194. DOI: https://doi.org/10.1016/ j.dcan.2017.03.002.

[20] Uskov, V., Pandey, A., Bakken, J. P., \& Margapuri, V. S. (2016). Smart engineering education: The ontology of Internet-of-Things applications. IEEE Global Engineering Education Conference, EDUCON, 10-13, April, 476-481. DOI https://doi.org/10.1109/EDUCON.2016.7474596

[21] Alnahdi, A., \& Liu, S. H. (2017). Mobile internet of things (MIoT) and its applications for smart environments: A positional overview. Proceedings - 2017 IEEE 2nd International Congress on Internet of Things, ICIOT 2017, 151-154. DOI https://doi.org/10.1109/IEEE.ICIOT.2017.26.

[22] Tianbo, Z., 2012, November. The internet of things promoting higher education revolution. In 2012 Fourth International Conference on Multimedia Information Networking and Security. 790-793. IEEE.

[23] Sklavos, N., Zaharakis, I. D., Kameas, A., \& Kalapodi, A. (2017). Security \& Trusted Devices in the Context of Internet of Things (IoT). Proceedings - 20th Euromicro Conference on Digital System Design, DSD 2017, 502-509. DOI : https://doi.org/10.1109/DSD.2017.81.

[24] Assante, D., Romano, E., Flamini, M., Castro, M., Martin, S., Lavirotte, S., Rey, G., Leisenberg, M., Migliori, M. O., Bagdoniene, I., Gallo, R. T., Pascoal, A., \& Spatafora, M. (2018). Internet of Things education: Labor market training needs and national policies. IEEE Global Engineering Education Conference, EDUCON, 2018-April, 1846-1853. DOI: https://doi.org/10.1109/ EDUCON.2018.8363459. 
[25] Bagheri, M., \& Movahed, S. H. (2017). The Effect of the Internet of Things (IoT) on Education Business Model. Proceedings - 12th International Conference on Signal Image Technology and Internet-Based Systems, SITIS 2016, 435-441. DOI https://doi.org/10.1109/SITIS.2016.74.

[26] Saravanan, K., Julie, E. G., \& Robinson, Y. H. (2019). Smart cities \& IoT: Evolution of applications, architectures \& technologies, present scenarios \& future dream. Intelligent Systems Reference Library, 154, 135-151. DOI :https://doi.org/10.1007/978-3-030-04203-5 7.

[27] Banica, L., Burtescu, E., \& Enescu, F. (2017). the Impact of Internet-of-Things in Higher Education. Scientific Bulletin : Economic Sciences, 16(1), 53-59.

[28] Roy, A., Zalzala, A. M. S., \& Kumar, A. (2016). Disruption of things: A model to facilitate adoption of IoT-based innovations by the urban poor. Procedia Engineering, 159(6), 199-209. DOI:

https://doi.org/10.1016/j.proeng.2016.08.159.

[29] Bhatt, J. and Bhatt, A., 2017 (2017). IoT Techniques to Nurture Education Industry: Scope \& Opportunities. International Journal on Emerging Technologies (Special Issue NCETST2017). 8(1), 128-132.

[30] Chatterjee, S., Kar, A. K., \& Gupta, M. P. (2018). Success of IoT in Smart Cities of India: An empirical analysis. Government Information Quarterly, 35(3), 349-361. DOI: https://doi.org/ 10.1016/j.giq.2018.05.002.

[31] Riggins, F. J., \& Wamba, S. F. (2015). Research directions on the adoption, usage, and impact of the internet of things through the use of big data analytics. Proceedings of the Annual Hawaii International Conference on System Sciences, 2015-March, 1531-1540. DOI: https://doi.org/ 10.1109/HICSS.2015.186.

[32] Xia, F., Yang, L.T., Wang, L. and Vinel, A. (2012). Internet of things. International journal of communication systems, 25(9), p.1101. DOI: https://doi.org/10.1002/dac.2417.

[33] Bogdanovic, Z., Simic, K., Milutinovic, M., Radenkovic, B., \& Despotović-Zrakic, M.
(2014). A platform for learning internet of things. Proceedings of the International Conference ELearning 2014 - Part of the Multi Conference on Computer Science and Information Systems, MCCSIS 2014, 2020(Raihan 2013), 259-266.

[34] Mathews, S. P., \& Gondkar, R. R. (2017). Solution Integration Approach using IoT in Education System. International Journal of Computer Trends and Technology, 45(1), 45-49.

DOI: https://doi.org/10.14445/22312803/ijcttv45p109.

[35] Plauska, I., \& Damaševi, R. (2014). Educational robots for Internet-of-Things supported collaborative learning. International Conference on Information and Software Technologies (pp. 346-358). Springer, Cham.

[36] Rico-Bautista, D., Medina-Cárdenas, Y., \& Guerrero, C. D. (2019). Smart University: A Review from the Educational and Technological View of Internet of Things. Advances in Intelligent Systems and Computing, 918, 427440. DOI: https://doi.org/10.1007/978-3-03011890-7 42.

[37] Chin, J., \& Callaghan, V. (2013). Educational living labs: A novel internet-ofthings based approach to teaching and research. Proceedings - 9th International Conference on Intelligent Environments, IE 2013, 92-99. DOI: https://doi.org/10.1109/IE.2013.48.

[38] Zhu, Z.-T., Yu, M.-H., \& Riezebos, P. (2016). A research framework of smart education. Smart Learning Environments, 3(1). DOI: https://doi.org/10.1186/s40561-016-00262 .

[39] Wang, Y. (2010). English Interactive Teaching Model which based upon Internet of Things Keywords- Internet of Things; English; Characteristics of. International Conference on Computer Application and System Modeling (ICCASM), 13(Iccasm), 587-590.

[40] Cornel, C., (2015). The Role of Internet of Things for a Continuous Improvement in Education. Hyperion Economic Journal, 3(2), 24-31. 
[41] Page, T. (2017). Opinions on the Internet of Things in the Industrial Design Curriculum. Design and Technology Education, 21(3), 14-28.

[42] Dlodlo, N., \& Kalezhi, J. (2015). The internet of things in agriculture for sustainable rural development. Proceedings of 2015 International Conference on Emerging Trends in Networks and Computer Communications, ETNCC 2015, 13-18. DOI: https://doi.org/10.1109/ETNCC. 2015.7184801.

[43] Ning, H. and Hu, S., 2012. Technology classification, industry, and education for Future Internet of Things. International Journal of Communication Systems, 25(9), 12301241. DOI : https://doi.org/10.1002/dac.2373.

[44] Duan, Y., Miao, M., Wang, R., Fu, Z., \& $\mathrm{Xu}, \mathrm{M}$. (2017). A framework for the successful implementation of food traceability systems in China. Information Society, 33(4), 226-242. DOI:

https://doi.org/10.1080/01972243.2017.1318325

[45] Bayani Abbasy, M., Corrales Ureña, M. A., León Brenes, R., \& Loaiza Berrocal, M. (2019). How IoT (Internet of Things) Can Shape Education. 2019, 1-11. DOI: https://doi.org/10.15359/ cicen.1.76.

[46] Moreira, F.T., Magalhães, A., Ramos, F. and Vairinhos, M. (2018). Citizen, Territory and Technologies: Smart Learning Contexts and Practices. Proceedings 2nd International Conference on Smart Learning Ecosystems and Regional Development (SLERD 2017). 1(80), $238 . \quad$ DOI: https://doi.org/10.1007/9783-319-61322-2.

[47] Mohapatra, S., Kumar, A. and Mohapatra, S., (2018). From a literature review to a conceptual framework for affordable quality healthcare service using internet of things (IOT) network. International Journal of Enterprise Network Management,9(1), 11-21. DOI: https://doi.org/10.1504/IJENM.2018.10013230.

[48] Elsaadany, A., \& Soliman, M. (2017). Experimental Evaluation of Internet of Things in the Educational Environment. International
Journal of Engineering Pedagogy (IJEP), 7(3), 50. DOI: https://doi.org/10.3991/ijep.v7i3.7187.

[49] Mehmood, R., Alam, F., Albogami, N. N., Katib, I., Albeshri, A., \& Altowaijri, S. M. (2017). UTiLearn: A Personalised Ubiquitous Teaching and Learning System for Smart Societies. IEEE Access, 5(c), 2615-2635. DOI: https://doi.org/10.1109/ACCESS.2017.2668840.

[50] Gao, L., \& Bai, X. (2014). A unified perspective on the factors influencing consumer acceptance of internet of things technology. Asia Pacific Journal of Marketing and Logistics, 26(2), 211-231. DOI: https://doi.org/10.1108/APJML-06-2013-0061.

[51] Mavroudi, A., Divitini, M., Gianni, F., Mora, S., \& Kvittem, D. R. (2018). Designing IoT applications in lower secondary schools. IEEE Global Engineering Education Conference, EDUCON, 2018-April, 1120-1126. DOI: https://doi.org/10.1109/EDUCON.2018.8363355

[52] Gómez, J., Huete, J. F., Hoyos, O., Perez, L., \& Grigori, D. (2013). Interaction system based on Internet of things as support for education. Procedia Computer Science, 21, 132139.

DOI:

https://doi.org/10.1016/j.procs.2013.09.019.

[53] Marquez, J., Villanueva, J., Solarte, Z. and Garcia, A. (2016). IoT in education: Integration of objects with virtual academic communities. In New Advances in Information Systems and Technologies. 5(6). 201-212. DOI: https://doi.org/10.1007/978-3-319-31232-3.

[54] STOICA, M., MIRCEA, M., GHILICMICU, B., \& USCATU, C. (2018). From a Smart Education Environment to an Eco-School through Fog \& Cloud Computing in IoT Context. Informatica Economica, 22(4/2018), 5-14. DOI: https://doi.org/10.12948/issn14531305/22.4.201 $\underline{8.01}$.

[55] Aldowah, H., U1 Rehman, S., Ghazal, S., \& Naufal Umar, I. (2017). Internet of Things in Higher Education: A Study on Future Learning. Journal of Physics: Conference Series, 892(1). 
DOI: 6596/892/1/012017.

https://doi.org/10.1088/1742-

[56] Gubbi, J., Buyya, R., Marusic, S., \& Palaniswami, M. (2013). Internet of Things (IoT): A vision, architectural elements, and future directions. Future Generation Computer Systems, 29(7), 1645-1660. DOI: https://doi.org/10.1016/j.future.2013.01.010.

[57] Maksimovic, M. (2017). Green Internet of Things (G-IoT) at engineering education institution: the classroom of tomorrow. InfotehJahorina, 16(3), 270-273.

[58] Abbasy, M. B., \& Quesada, E. V. (2017). Predictable Influence of IoT (Internet of Things) in the Higher Education. International Journal of Information and Education Technology, 7(12), 914-920. DOI: https://doi.org/10.18178/ijiet.2017.7.12.995.

[59] Kortuem, G., Bandara, A. K., Smith, N., Richards, M., \&Petre, M. (2013). Educating the Internet- of-Things Generation [Educar a la generación de Internet de las cosas]. February, 53-61.

[60] Gul, S., Asif, M., Ahmad, S., Yasir, M., Majid, M., \& Malik, M. S. A. (2017). A Survey on role of Internet of Things in education. IJCSNS International Journal of Computer Science and Network Security, 17(5), 159-165.

[61] Kiryakova, G., Yordanova, L., \& Angelova, N. (2017). Can we make Schools and universities smarter with the Internet of Things? TEM Journal, 6(1), 80-84. DOI: https://doi.org/10.18421/ TEM61-11.

[62] Project ERASMUS, ALIOT, \& Kharchenko, V. S. E. (2019). Internet of Things for Industry and Human Applications. Volume 1. Fundamentals and Technologies. Retrieved on 15/04/2020 from https://aliot.eu.org/

[63] Hariharasudan, A., \& Kot, S. (2018). A scoping review on Digital English and Education 4.0 for Industry 4.0. Social Sciences, 7(11). DOI: https://doi.org/10.3390/socsci7110227.

[64] Sean Dieter Tebje Kelly, Nagender Kumar Suryadevara, \& Subhas Chandra Mukhopadhyay, (2013). Towards the
Implementation of IoT for Environmental Condition Monitoring in Homes. IEEE SENSORS JOURNAL, 13(10), 3846-3853.

[65] Kassab, M., Defranco, J. F., \&Voas, J. (2018). Smarter Education. IT Professional, 20(5), 20-24. DOI: https://doi.org/10.1109/MITP.2018.053891333.

[66] Raju R Gondkar, (2018). Solution Integration Approach using IoT in Education System. International Journal of Emerging Trends \& Technology in Computer Science, 45(1), DOI: https://doi.org/10.14445/22312803/IJCTTV45P109.

[67] Kassab M, DeFranco J, Laplante P. A, Systematic literature review on Internet of things in education: Benefits and challenges. Journal of Computer Assist Learning. 2019. 1-13. DOI: https://doi.org/10.1111/jcal.12383.

[68] Shaikh, H., Khan, M. S., Mahar, Z. A., Anwar, M., Raza, A., \& Shah, A. (2019). A conceptual framework for determining acceptance of internet of things (IoT) in higher education institutions of Pakistan. 2019 International Conference on Information Science and Communication Technology, ICISCT 2019, $1-5$.

DOI:

https://doi.org/10.1109/CISCT.2019.8777431.

[69] Haroon, A., Ali, M., Asim, Y., Naeem, W., Kamran, M., \& Javaid, Q. (2016). Constraints in the IoT: The World in 2020 and Beyond. International Journal of Advanced Computer Science and Applications, 7(11), 252271.

DOI: https://doi.org/10.14569/ijacsa.2016.071133.

[70] van Niekerk, B., Pretorius, B. H., Ramluckan, T., \& Patrick, H. (2018). The Impact of IoT on Information Warfare. 2(2), 141-164. DOI: https://doi.org/10.4018/978-1-5225-4763$1 . \operatorname{ch} 005$.

[71] Leiton, K., \&Loaiza, M. (2017). Internet of Things (IoT) Advantages on E-Learning in the Smart Cities. International Journal of Development Research. 07(12), 17747-17753.

[72] Caviglione, L., \& Coccoli, M. (2018). Smart e-learning systems with big data. 
International Journal of Electronics and Telecommunications, 64(4), 445-450. DOI: https://doi.org/10.24425/123544.

[73] Songsom, N., Nilsook, P., Wannapiroon, P., Fung, C. C., \& Wong, K. W. (2019). System architecture of a student relationship management system using Internet of Things to collect digital footprint of higher education institutions. International Journal of Emerging Technologies in Learning, 14(23), 125-140. DOI: https://doi.org/10.3991/ijet.v14i23.11066.

$* * * * * * * * * * * * * * * *$ 